\title{
Mafic alkaline intrusions in the Damodar Valley, India: the micaceous kimberlite - lamproite connection revisited
}

\author{
Kent, R.W. ${ }^{1}$, Paul, D.K. ${ }^{2}$, Basu, A. ${ }^{3}$, Ghose, N.C. ${ }^{4}$ and Kempton, P.D. ${ }^{5}$ \\ 1. Department of Geology, University of Leicester, University Road, Leicester LE1 7RH, United Kingdom \\ 2. Indian School of Mines, Dhanbad 826004 , Bihar, India \\ 3. Central Petrological Laboratory, Geological Survey of India, 15 Kyd Street, Calcutta 700016 , India \\ 4. Department of Geology, Patna University, Patna 800 005, Bihar, India \\ 5. NERC Isotope Geosciences Laboratory, Keyworth, Nottingham NG12 5GG, United Kingdom
}

\section{Introduction}

Small-volume mafic alkaline igneous rocks in India have received little attention during this century, perhaps being overshadowed by their diamond-rich counterparts in Australia, Botswana, Russia, the Congo and South Africa. In recent years, there has been renewed interest in India as a region for diamond exploration, prompted by discoveries of diamondiferous rocks at Raipur, Madhya Pradesh, and in the Mahbubnagar district, Andhra Pradesh. Less well known is a suite of early Cretaceous micaceous kimberlite ('orangeite')-like rocks that crops out in the Damodar Valley, Bihar-West Bengal (Fig. 1). These rocks resemble South African micaceous kimberlites in mineralogy and geochemistry, and mafic alkaline intrusions from Brazil (the Alto Paranaíba province) and Russia (Archangelsk) in Nd-Sr isotopic composition (Kent et al., 1998a, b). The Damodar Valley rocks are unusual also in their mode of occurrence, cropping out as thin dykes and sub-horizontal cylindrical sills within coal seams (e.g. Kent et al., 1992). This paper outlines the distribution, age and nomenclature of the Damodar Valley mafic alkaline rocks.

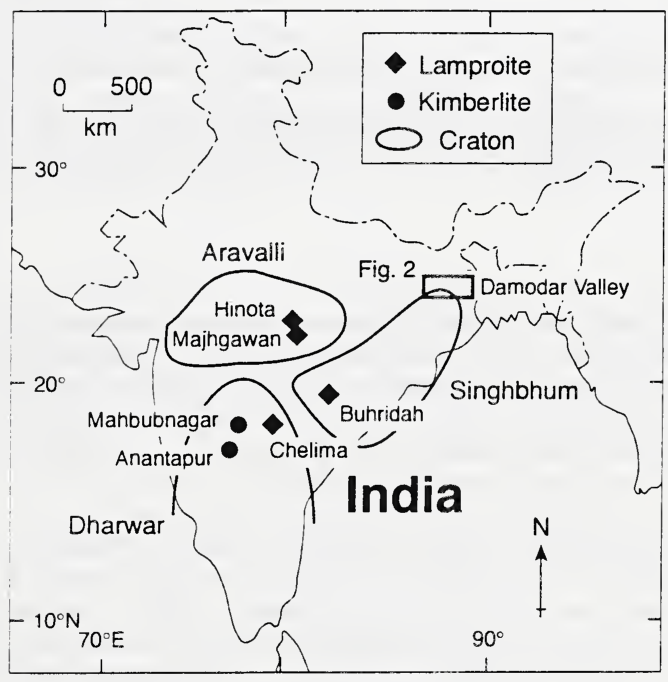

Fig. 1. Map showing the location of lamproites and kimberlites in India and their relationship to Archaean cratons (modified from Chalapathi Rao et al., 1996). The Damodar Valley alkaline province lies on the northern margin of the Singhbhum craton.

\section{Distribution and age}

The Damodar Valley alkaline province lies on the northern margin of the Singhbhum craton, within a Proterozoic mobile belt (the $>1.4 \mathrm{Ga}$ Chotanagpur plateau; Fig. 2). The number of alkaline intrusions is greatest (several hundred) in the eastern part of the Damodar Valley, notably in the Bokaro, Jharia and Raniganj basins (e.g. Middlemost et al., 1988; Rock et al., 1992; Basu et al., 1997). The location of the intrusions appears to have been controlled by the east-west-trending Damodar Valley extensional fault system, which may be the surface manifestation of a deep basement shear zone (Mazumdar, 1988). 
The Damodar Valley alkaline rocks have K-Ar (biotite and whole-rock) ages of 113-105 Ma (Sarkar et al., 1980). In a recent study, Kent et al. (1998a) obtained an ${ }^{40} \mathrm{Ar} /{ }^{39} \mathrm{Ar}$ total-fusion isochron age of $113.5 \pm 0.5 \mathrm{Ma}$ (1s error) on phlogopite separated from a Damodar Valley mafic alkaline rock. This age was interpreted as being close to the true crystallisation age. Two other phlogopite separates gave ${ }^{40} \mathrm{Ar} /{ }^{39} \mathrm{Ar}$ laser ablation ages of $116.6 \pm 0.8 \mathrm{Ma}$ and $109.1 \pm 0.7 \mathrm{Ma}(1 \mathrm{~s}$ errors), respectively; these ages appear to reflect partial alteration of the phlogopite grains. Coincidentally, the age of the Damodar Valley samples is similar to that of most South African micaceous kimberlites ( $\mathrm{Rb}-\mathrm{Sr}$ ages of 125-110 Ma, with several 'outliers' having ages of $>130$ Ma; Skinner, 1989).

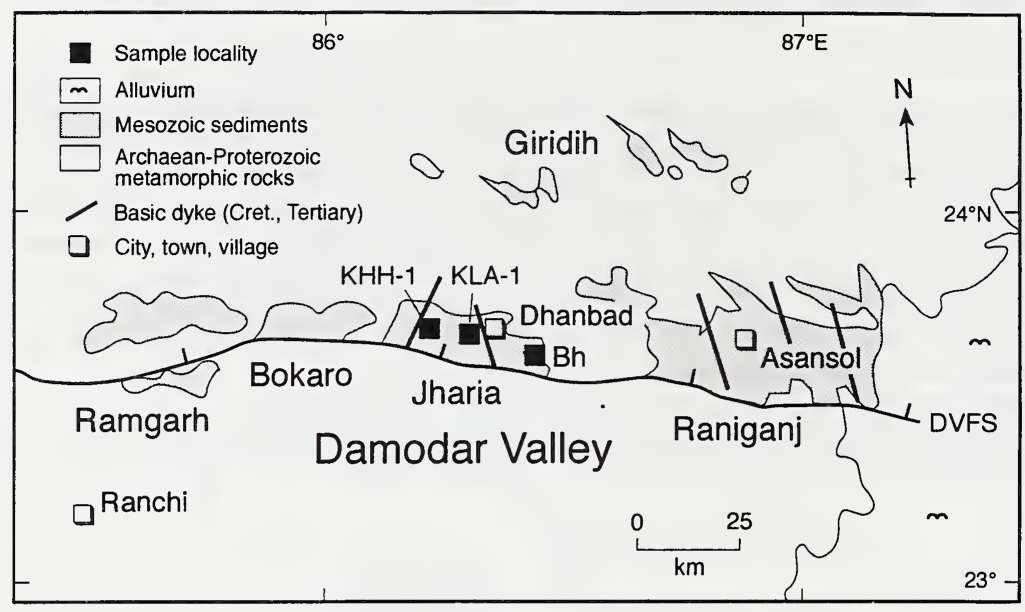

Fig. 2. Map of the eastern Damodar Valley, Bihar/West Bengal, eastern India, showing selected sample localities in the Jharia and Raniganj basins. Basic dykes are shown schematically. Key: Bh $=$ Bhowrah, DVFS = Damodar Valley Fault System.

\section{Classification}

The nomenclature of mafic alkaline igneous rocks is confusing to specialists and nonspecialists alike. In attempting to classify the Damodar Valley alkaline rocks, Kent et al. (1998a) followed the mineralogical-genetic nomenclature of Mitchell (1995, p.10-14), using his definition of micaceous kimberlites (orangeites) as "a clan of ultrapotassic peralkaline volatilerich ... rocks, characterised by the presence of phlogopite macrocrysts and microphenocrysts ... groundmass micas" and, commonly, rounded olivine macrocrysts.

We observe that the Damodar Valley alkaline rocks contain microphenocrystal and groundmass phlogopite-tetraferriphlogopite, microphenocrystal apatite, rutile and prismatic crystals of K-triskaidecatitanate $\left(\mathrm{K}_{2} \mathrm{Ti}_{13} \mathrm{O}_{27}\right.$; Mitchell, 1995). Macrocrystal olivine (usually serpentinised) and primary microphenocrystal and groundmass diopside or aegirine are present in some samples. Damodar Valley alkaline rocks also contain sanidine, K-richterite, perovskite, monazite, ilmenite and a varied assemblage of carbonates, including one or all of calcite, ferroan dolomite, strontianite, breunnerite and strontian witherite (cf. Rock et al., 1992). Thus, these rocks conform to Mitchell's (1995) mineralogical definition of orangeite. Evolved varieties from our sample collection, which resemble sanidine richterite lamproites (sensu Mitchell and Bergman, 1991; see also Tainton and Browning, 1991), can be termed 'richterite sanidine orangeites'. The latter suggest a mineralogical convergence of differentiated members of the orangeite clan with lamproitic rocks.

The only 'flies in the ointment' are that our Damodar Valley samples are not usually peralkaline (most have molar $\left(\mathrm{K}_{2} \mathrm{O}+\mathrm{Na}_{2} \mathrm{O}\right.$ ) $/ \mathrm{Al}_{2} \mathrm{O}_{3}<1$ ) or perpotassic (most have molar $\mathrm{K}_{2} \mathrm{O} / \mathrm{Al}_{2} \mathrm{O}_{3}$ $<1)$. The Indian rocks also differ from most South African orangeites in $\mathrm{Nd}-\mathrm{Sr}$ isotopic composition (Fig. 3; for data and discussion, see Kent et al., 1998b). Our samples resemble isotopically the anomalous Prieska orangeites of South Africa, mafic alkaline igneous rocks from the Alto Paranaíba province, Brazil, and samples of 'micaceous kimberlite' and 'olivine lamproite' from Archangelsk, northeast Russia. 


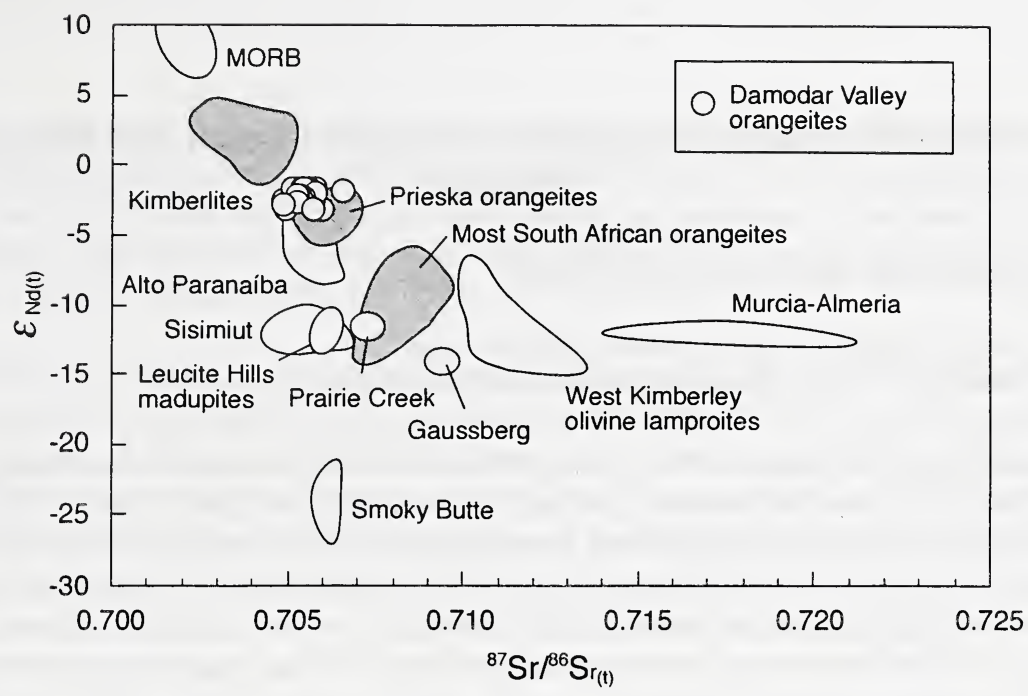

Fig. 3: Nd-Sr isotope diagram showing the compositions of Damodar Valley micaceous kimberlites (orangeites) relative to other mafic alkaline igneous rocks. Data for the Damodar Valley rocks is from Middlemost et al. (1988), Rock et al. (1992) and Kent et al. (1998b).

\section{Summary and conclusions}

Early Cretaceous mafic alkaline igneous rocks cropping out in the Damodar Valley, Bihar, India, can be classified as micaceous kimberlites (orangeites). Highly-differentiated varieties are mineralogically similar to sanidine richterite lamproites, suggesting a convergence between the orangeite and lamproite clans. The Damodar Valley micaceous kimberlites are potentially diamondiferous; however, diamond grade is yet to be established.

\section{References}

Basu, A., Bhattacharya, A.K. and Paul, D.K., 1997, Petrology and geochemistry of the lamprophyric rocks from the Bokaro coalfield, Bihar and their economic potential: J. Geol. Soc. India, 50, p. 255-266.

Chalapathi Rao, N.V.C., Miller, J.A., Pyle, D.M. and Madhavan, V., 1996, New Proterozoic K-Ar ages for some kimberlites and lamproites from the Cuddapah Basin and Dharwar Craton, South India: evidence for non-contemporaneous emplacement: Precam. Res., 79, p. 363-369.

Kent, R.W., Ghose, N.C., Paul, P.R., Hassan M.J. and Saunders, A.D., 1992, Coal-magma interaction: an integrated model for the emplacement of cylindrical intrusions: Geol. Mag., 129, p. 753-762.

Kent, R.W., Kelley, S.P. and Pringle, M.S., 1998, Mineralogy and ${ }^{40} \mathrm{Ar} /{ }^{39} \mathrm{Ar}$ geochronology of orangeites (Group II kimberlites) from the Damodar Valley, eastern India: Mineral. Mag., 62, in press.

Kent, R.W., Saunders, A.D., Kempton, P.D. and Ghose, N.C., 1998, Petrology of orangeites (micaceous kimberlites) from the Damodar Valley, eastern India: J. Petrology, submitted.

Mazumdar, S.K., 1988, Crustal evolution of the Chotanagpur Gneissic Complex and the Mica Belt of Bihar: Mem. Geol. Soc. India, 8, p. 49-83.

Middlemost, E.A.K., Paul, D.K. and Fletcher, I.R., 1988, Geochemistry and mineralogy of the minettelamproite association from the Indian Gondwanas: Lithos, 22, p. 31-42.

Mitchell, R.H., 1995, Kimberlites, orangeites, and related rocks: Plenum Press, New York, 410 pp.

Mitchell, R.H. and Bergman, S.C., 1991, Petrology of lamproites: Plenum Press, New York, 447 pp.

Rock, N.M.S., Griffin, B.J., Edgar, A.D., Paul, D.K. and Hergt, J.M., 1992, A spectrum of potentially diamondiferous lamproites and minettes from the Jharia coalfield, eastern India: J. Volcanol. Geotherm. Res., 50, p. 55-83.

Sarkar, A., Paul, D.K., Balasubrahmanyan, M.N. and Sengupta, N.R., 1980, Lamprophyres from Indian Gondwanas - K-Ar ages and chemistry: J. Geol. Soc. India, 21, p. 188-193.

Skinner, E.M.W., 1989, Contrasting Group I and II kimberlite petrology: towards a genetic model for kimberlites. In: Kimberlites and related rocks. Vol. 1. Their composition, occurrence, origin and emplacement (Ross, J., Jaques, A.L., Ferguson, J., Green, D.H., O'Reilly, S.Y., Danchin, R.V. and Janse, A.J.A., eds), Geol. Soc. Austral. Spec. Publ., 14, pp. 528-544.

Tainton, K.M. and Browning, P., 1991, The Group II kimberlite - lamproite connection: some constraints from the Barkly West district, northern Cape Province, South Africa: Fifth Int. Kimb. Conf., Araxa, Brazil, Ext. Abstr., CPRM Spec. Publ., 2/91, p. 405-407. 